\title{
Plasma Levels of TNF-al and IL-10 in Plasmodium falciparum co-infection with Mycobacterium tuberculosis
}

Mathew Folaranmi OLANIYAN ${ }^{1} * * *$, Seun Bolanle OLADUNJOYE ${ }^{2}$, and Temitayo AFOLABI ${ }^{2}$

${ }^{1}$ Department of Medical Laboratory Science, Edo University, Iyamho-Nigeria

2.Department of Medical Laboratory Science, Achievers University, Owo-Nigeria

1*** Principal/Corresponding Author: e-mail: olaniyanmat@yahoo.com OR olaniyanmat@gmail.com

TEL: +2348052248019; +2347033670802

\begin{abstract}
$\mathrm{TNF} \alpha$ is a proinflammatory cytokine which acts to worsen disease while IL-10 is an anti-inflammatory cytokine, which acts to improve healing. Plasmodium falciparum co-infection with Mycobacterium tuberculosis could generate both innate and acquired immunity involving inflammatory responses. This work was designed to determine plasma level of TNF-Alpha and IL-10 in plasmodium co-infection with Mycobacterium tuberculosis. The test subjects recruited for this study were M. tuberculosis mono-infected patients (30), Plasmodium falciparum mono-infected patients (50) and M. tuberculosis and plasmodium coinfected patients (30) aged 32-73years. M. tuberculosis and plasmodium non-infected subjects (50) were studied as control. All subjects were seronegative to HIV, HCV and HBsAg. TNF-Alpha, IL-10, HIV, $\mathrm{HCV}$ and HBsAg were determined in each of the subjects by immunochemical technique using ELISA method. M. tuberculosis was identify in each of the subjects by fluorescence microscopy and sputum culture on Löwenstein-Jensen medium while identification of plasmodium was carried out using thick and thin film technique using Geimsha and leishman staining.

The result obtained showed a significantly higher plasma levels of TNF-alpha and IL-10 in patients who were co-infected with both plasmodium and M. tuberculosis compared with Plasmodium falciparum mono-infected, $M$. tuberculosis mono-infected patients and also compared with the control subjects $(\mathrm{p}<0.05)$. This work reveals a significant increase in plasma value of TNF-alpha and IL-10 in M. tuberculosis and plasmodium co-infections compared with either plasmodium or M.tuberculosis mono-infections. Routine laboratory evaluation of these parameters in $M$. tuberculosis and plasmodium co-infection will provide useful direction for the management of the disease condition.
\end{abstract}

Keywords: TNF- $\alpha$ l, IL-10, plasmodium co-infection, Mycobacterium tuberculosis

Received: 08/05/2018

Accepted: $02 / 06 / 2018$

DOI: https://dx.doi.org/10.4314/jcas.v14i2.1

C The Authors. This work is licensed under the Creative Commons Attribution 4.0 International Licence. 
REVUE DE L'ACADEMIE DES SCIENCES DU CAMEROUN Vol. 14 No. 2 (2018) 


\section{Introduction}

Plasmodium and Mycobacterium tuberculosis constitutes main causes of death with respect to infectious diseases in Nigeria and Worldwide. The immunological studies of these pathogenic agents have been given less attention compared to the co-infection of Human Immunodeficiency virus and viral Hepatitis (Jannike et al., 2016)

$M$. tuberculosis is a life threatening airborne infection, which has been very difficult to manage until recently when foreign donor agents like Damien Foundation, CDC, intervened in Nigeria. Nigeria is the country the worst affected by tuberculosis in Africa and ranks third in the world (CDC, 2016).

Plasmodium falciparum and Mycobacterium tuberculosis infection could affect the immunity of infected patients. Each of the aforementioned infections constitutes a major cause of death in Africa. Excessive utilization of the immune system to produce antibodies as a specific response to these deadly infections could weaken the immune system, which could lead to immunosuppression. This could also enhance the invasion of opportunistic agents. Mycobacterium tuberculosis infection majorly affects the lung and could be systemic affecting organs, tissues and cells including those of immune system (Walsh et al., 1991; Braat et al., 2006). The causative agents of the two infectious diseases are widely spread through the air for Mycobacterium tuberculosis and through the female anopheles mosquito vector for Plasmodium infection. These two infectious diseases are tropical and highly prevalent in Nigeria and in Africa countries

Plasmodium falciparum and Mycobacterium tuberculosis could generate inflammatory responses which could affect the plasma levels of cytokines. Cytokines are inflammatory agents which have their levels increased in any inflammatory response. Cytokines could be broadly classify into anti and pro-inflammatory cytokines. The expression of anti-inflammatory cytokines favours convalescence and reduce the severity of the infectious diseases. The expression of proinflammatory cytokines is an indication of poor prognosis and could worsen the disease process. IL-10 (Interleukin 10) is an antiinflammatory agent encoded by IL-10 gene while TNF alpha is a pro-inflammatory agent coded by what gene? These two agents could generate responses leading to changes in the plasma concentration of IL-10 and TNF alpha (Walsh et al., 1991; Braat et al., 2006).

Little attention has been paid to the immunochemical status of the co-infection of Plasmodium falciparum with $M$. tuberculosis compared to co-infections of HIV and viral hepatitis with other infectious agents hence the justification for this research work. This work aims at the determining the plasma levels of TNFá and 1L-10 in plasmodium co-infection with Mycobacterium tuberculosis to see whether they correlate with disease status

\section{Materials and Methods}

The study was carried out in Saki West at Baptist Medical Centre Saki-Nigeria. Saki West is a Local Government Area in Oyo State, Nigeria. Its headquarters are in the town of Saki. It has an area of 2,014 $\mathrm{km}^{2}$ and a population of 278,002 at the 2006 census. Shaki,Nigeria is located at the extreme end of Oyo state. It has a Ressetlement center of 2nd Mechanised Division of Nigerian Army, The Oke-Ogun Polytechnic, and a technical college. Shaki,Nigeria is also one of the largest cities in Oyo state. The postal code of the area is 203.

\section{Study population}

The study population was determined using the sample size formula (Vaus, 2002) . One hundred and sixty subjects classified into control subjects who were neither infected with Plasmodium falciparum nor Mycobacterium tuberculosis $(\mathrm{n}=50)$; Plasmodium infected subjects $(\mathrm{n}=50)$; 
Mycobacterium tuberculosis subjects $(\mathrm{n}=30)$ and Plasmodium co-infected with Mycobacterium tuberculosis patients $(\mathrm{n}=30)$ aged 32 to 73 years were recruited for the study from Saki-west local Government of Oyo State. Subjects who were seronegative to $\mathrm{HBsAg}$, HCV and HIV were included in the study.

\section{Methods}

\section{TNF alpha ELISA}

Plasma TNF alpha was analysed using Abcam's kit. Abcam's TNF alpha Human in vitro ELISA (Enzyme-Linked Immunosorbent Assay) kit is designed for the quantitative measurement of TNF alpha in supernatants, buffered solutions, serum and plasma samples.

A monoclonal antibody specific TNF alpha has been coated onto the wells of the microtiter strips provided. Samples, including standards of known TNF alpha concentrations, control specimens or unknowns are pipetted into these wells. During the first incubation, the standards or samples and a biotinylated monoclonal antibody specific for TNF alpha are simultaneously incubated. After washing, the enzyme Streptavidin-HRP, that binds the biotinylated antibody is added, incubated and washed. A TMB substrate solution is added which acts on the bound enzyme to induce a colored reaction product. The intensity of this colored product is directly proportional to the concentration of TNF alpha present in the samples.

\section{IL-10 ELISA}

Plasma IL-10 was analysed using Abcam's kit. Abcam's IL-10 (Interleukin-10) Human in vitro ELISA (Enzyme-Linked Immunosorbent Assay) kit is designed for the quantitative measurement of IL-10 in supernatants, buffered soloutions, serum and plasma samples.

A monoclonal antibody specific for IL-10 has been coated onto the wells of the microtiter strips provided. Samples, including standards of known
IL-10 concentrations, control specimens or unknowns are pipetted into these wells. During the first incubation, the standards or samples and a biotinylated monoclonal antibody specific for IL-10 are simultaneously incubated. After washing, the enzyme Streptavidin-HRP, that binds the biotinylated antibody is added, incubated and washed. A TMB substrate solution is added which acts on the bound enzyme to induce a colored reaction product. The intensity of this colored product is directly proportional to the concentration of IL-10 present in the samples.

\section{Laboratory Identification of Plasmodium falciparum}

Laboratory diagnosis of malaria was carried out by Microscopy as described by Cheesbrough (2002).

Microscopic Examination of Thick and thin blood smear was used for the identification of plasmodium in the blood of the subjects.

Thick and thin blood smear study is the gold standard method for malaria diagnosis. The procedure follows these steps: collection of peripheral blood, staining of smear with Giemsa stain and examination of red blood cells for malaria parasites under the microscope.

Thick smear. It is not fixed in methanol; this allows the red blood cells to be hemolyzed, and leukocytes and any malaria parasites present will be the only detectable elements. However, the hemolysis may lead to distorted plasmodial morphology making plasmodium species differentiation difficult. Therefore, thick smears are mainly used to detect infection and to estimate parasitemia.

Thin smear. It is fixed in methanol. Thin smears allow the examiner to identify malaria species, quantify parasitemia, and recognize parasite forms like schizonts and gametocytes. 


\section{Anti HCV ELISA Assay}

This was assayed using Anti-Hepatitis C Virus Core Antigen antibody (ab50288) Abcam kit. The hepatitis $\mathrm{C}$ virus (HCV) core protein represents the first 191 amino acids of the viral precursor polyprotein and is cotranslationally inserted into the membrane of the endoplasmic reticulum. Hepatitis $\mathrm{C}$ virus (HCV) core is a viral structural protein; it also participates in some cellular processes, including transcriptional regulation. However the mechanisms of coremediated transcriptional regulation remain poorly understood. Hepatitis $\mathrm{C}$ virus (HCV) core protein is thought to contribute to HCV pathogenesis through its interaction with various signal transduction pathways. In addition, HCV core antigen is a recently developed marker of hepatitis $\mathrm{C}$ infection. The $\mathrm{HCV}$ core protein has been previously shown to circulate in the bloodstream of $\mathrm{HCV}$-infected patients and inhibit host immunity through an interaction with $\mathrm{gC} 1 \mathrm{qR}$. Hepatitis C Virus is a positive, single stranded RNA virus in the Flaviviridae family. The genome is approximately 10,000 nucleotides and encodes a single polyprotein of about 3,000 amino acids. The polyprotein is processed by host cell and viral proteases into three major structural proteins and several non structural proteins necessary for viral replication. Hepatitis $\mathrm{C}$ virus (HCV) causes most cases of non- $A$, non-B hepatitis and results in most $\mathrm{HCV}$ infected people developing chronic infections, liver cirrhosis and hepatocellular carcinoma. T cell responses, including interferongamma production are severely suppressed in chronic HCV patients.

\subsubsection{HIV ELISA Test}

HIV test was carried out using Genscreen ${ }^{\text {TM }}$ ULTRA HIV Ag-Ab Biorad Kit.

CLINICAL VALUE The acquired immunodeficiency syndrome (AIDS) is a virus inducing infectious disease characterised by strongly depressed immunity. Two types of viruses related to the Lentivirus group have been isolated from lymphocytes of patients suffering from AIDS or its prodromes. The first one, named HIV-1, was isolated in France then in the United States. The second one, named HIV-2 was isolated from two patients living in Africa and has proved to be responsible for a new AIDS focus in West Africa. Knowledge on genetic variability of the HIV virus strains was acquired by sequencing the GAG, POL, and ENV genes of the representative strains of each subtype. The HIV-1 viruses are divided into 2 groups : the $\mathrm{M}$ group, including 9 sub-types (A to I) and the O group. The HIV-2 virus includes 5 sub-types. The geographical distribution of the different sub-types is now quite well defined. Some HIV-1 variants have only $70 \%$ homology for the GAG and POL genes with the main isolates and only $50 \%$ for the ENV gene; these differences can explain the failure of the diagnosis of infection in some patients. The various HIV-2 isolates share common antigens with the SIV simian virus in all proteins (envelope proteins and core proteins : heterology $=30 \%$, but exhibit less than $40 \%$ homology with the HIV-1 envelope proteins. HIV antigens and antibodies appear and are detectable at different stages of the seroconversion and of the infection. The Genscreen ${ }^{\mathrm{TM}}$ ULTRA HIV Ag$\mathrm{Ab}$ allows the simultaneous detection of anti-HIV1 ( $\mathrm{M}$ and $\mathrm{O}$ groups) and anti-HIV-2 antibodies and antigens.

PRINCIPLE OF THE TEST; The Genscreen $^{\text {TM }}$ ULTRA HIV Ag-Ab is an enzyme immunoassay based on the principle of the sandwich technique for the detection of HIV antigen and of the various antibodies associated with HIV-1 and/or HIV-2 virus in human serum or plasma. The solid phase is coated with :

- monoclonal antibodies against p24 HIV-1 antigen - purified antigens : gp160 recombinant protein, a synthetic peptide mimicking a totally artificial (i.e. encoded by no existing virus) HIV-1 group O-specific epitope and a peptide mimicking the immunodominant epitope of the HIV-2 envelope 
protein. The conjugates are based upon the use of :

- biotinylated polyclonal antibodies to HIV Ag (conjugate 1)

- Streptavidin and HIV antigens - peroxidase conjugate (gp41 and gp36 peptides mimicking the immunodominant epitopes of the HIV-1 and HIV2 envelope glycoproteins, and the same synthetic peptide mimicking a totally artificial HIV-1 group O-specific epitope used for the solid phase) (conjugate 2) The assay procedure includes the following reaction steps : 1 . Conjugate 1 (biotinylated polyclonal antibody to p24 HIV-1 $\mathrm{Ag}$ ) is added into the microplate wells. 2. Serum samples to be assayed and controls are pipetted into the wells.

- If present, HIV antigens bind with the monoclonal antibody bound to the solid phase and the conjugate 1

- HIV-1 and/or HIV-2 antibodies, if any, bind to the antigens immobilised on the solid phase.

- Deposition of conjugate 1 and sample is validated through a colour change, from yellowgreen to blue. 3. After incubation at $37^{\circ} \mathrm{C}$ then washing, conjugate 2 is added :

- Streptavidin react with biotinylated $\mathrm{Ab}-\mathrm{Ag}-\mathrm{Ab}$ complexes

- Peroxidase labelled, purified HIV-1 and HIV-2 antigens bind in turn to the $\operatorname{IgG}, \operatorname{IgM}$ or $\operatorname{IgA}$ antibodies captured on the solid phase. 64 . After incubation at $18-30^{\circ} \mathrm{C}$ the unbound conjugate 2 fraction is removed by washing. After incubation in presence of the substrate at room temperature $\left(18-30^{\circ} \mathrm{C}\right)$ the presence of the complexed conjugate is shown by a change of colour. 5 . The reaction is stopped and absorbances are read using a spectrophotometer at 450/620-700 $\mathrm{nm}$. The absorbance measured on a sample determines the presence or absence of HIV Ag or HIV-1 and/or HIV-2 antibodies

\section{HBsAg ELISA Test}

This was assayed using Diagnostic automation/ Cortez Diagnostics, INC kit by ELISA method HBsAg ELISA Kit Background Information Hepatitis B infection is spread through infected blood or body secretions of infected individuals. Since Hepatitis B virus (HBV) is known as one of the major causes of blood transmitted hepatitis infections, blood screening using the HBsAg ELISA test is one of the most effective ways of preventing the spread of HBV. When using this kit, it is important to classify hepatitis $B$ infection through three phases of the infection - incubation, acute, and convalescent. This can be done by identifying serological markers through each phase. Knowing the serological markers of HBsAg is an excellent method for the diagnosis and treatment of infected individuals. Symptoms of HBV infection can range from mild to severe, including chronic liver disease (cirrhosis and carcinoma). HBV is an enveloped, double-stranded DNA virus belonging to the Hepadnaviridae family. The outer envelope surface antigen of the Hepatitis B virus is $\mathrm{HBsAg}$. It contains the determinant " $\mathrm{a}$ " and is identified in two subgroups (ay and ad). HBV has four HBsAg subtypes (adw, ady, ayw, and ayr) and has 10 major serotypes. HBsAg can be identified two to four weeks before the ALT levels are abnormal, and three to five weeks before symptoms appear. HBsAg elisa assay is one of the best methods available for either screening blood donors or in the clinical diagnosis of hepatitis B-infected individuals.

\section{HBsAg ELISA Assay Kit Principle}

The HBsAg ELISA Test kit employs an antibody sandwich ELISA technique where monoclonal antibodies unique to $\mathrm{HBsAg}$, are pre-coated on polystyrene microwell strips. The serum or plasma sample is added together with a second antibody, the HRP Conjugate, (horseradish peroxidase) and directed against a different epitope of $\mathrm{HBsAg}$. Throughout the time of incubation, specific 
immunocomplex that may have formed (indicating presence of $\mathrm{HBsAg}$ ) is captured on the solid phase. After washing, to eliminate serum proteins and unbound HRP-conjugate, chromogen solutions containing tetramethylbenzidine (TMB) and urea peroxide are added to the wells. Next, the colorless chromogens are hydrolyzed by the bound HRP-conjugate to a blue-colored product while in the presence of the antibody-antigen-antibody (HRP) sandwich immunocomplex. Halting the reaction with sulfuric acid, the blue color then turns yellow. The color intensity can be gauged proportionally to the amount of antigen captured in the wells, and to the amount in the sample, respectively. The wells remain colorless if the $\mathrm{HBsAg}$ result is negative.

\section{Identification of Mycobacterium tuberculosis in sputum using fluorescence microscopy (auramine-rhodamine staining), \\ Principle}

The specimen is illuminated with light of a specific wavelength (or wavelengths) which is absorbed by the fluorophores, causing them to emit light of longer wavelengths (i.e., of a different color than the absorbed light). The illumination light is separated from the much weaker emitted fluorescence through the use of a spectral emission filter. Typical components of a fluorescence microscope are a light source (xenon arc lamp or mercury-vapor lamp are common; more advanced forms are highpower LEDs and lasers), the excitation filter, the dichroic mirror (or dichroic beam splitter), and the emission filter. The filters and the dichroic beam splitter are chosen to match the spectral excitation and emission characteristics of the fluorophore used to label the specimen (Spring, 2008). In this manner, the distribution of a single fluorophore (color) is imaged at a time. Multicolor images of several types of fluorophores must be composed by combining several singlecolor images (Spring and Davidson, 2008).

Most fluorescence microscopes in use are epifluorescence microscopes, where excitation of the fluorophore and detection of the fluorescence are done through the same light path (i.e. through the objective). These microscopes are widely used in biology and are the basis for more advanced microscope designs, such as the confocal microscope and the total internal reflection fluorescence microscope (TIRF)

\section{Sputum culture for the Identification of} Mycobacterium tuberculosis

In addition to fluorescence microscopy Sputum was inoculated on Löwenstein-Jensen medium and incubated aerobically for 4 weeks. The follwoign features were also used for the identification of the growth on the medium a brown, granular colonies (sometimes called "buff, rough and tough").

\section{Ethical Considerations and Clearances}

The proposal of this work was reviewed and approved by ethical and research committee of Baptist Medical center Saki-Nigeria before the commencement of this work. Informed consent was also obtained from each of the patient and control subjects.

\section{Method of Statistical Analysis}

The results obtained were subjected to statistical analysis using SPSS 18.0 to determine mean, standard deviation, probability, student " $\mathrm{t}$ " test and level of significant at 0.05 .

\section{Results}

There was a significantly higher plasma IL-10 in patients co-infected with Plasmodium and mycobacterium tuberculosis than the result obtained from the control subjects, Plasmodium monoinfected patients and Mycobacterium tuberculosis mono-infected subjects with $\mathrm{p}<0.05$ (table 1 and 5 , figure 1).

There was a significantly higher plasma TNF alpha in mycobacterium tuberculosis and Plasmodium coinfected patients than the control subjects and mycobacterium tuberculosis mono-infected patients with $\mathrm{p}<0.05$ (table 1 and 5, figure 1).

However, there was no significant difference in the plasma value of IL-10 and TNF alpha in mycobacterium tuberculosis mono-infected patients and 
plasmodium mono-infected patients compared with the control subjects with $\mathrm{p}>0.05$. There was no significant difference in the plasma value of IL-10 and TNF alpha in mycobacterium tuberculosis monoinfected patients compared with Plasmodium mono-infected patients with $\mathrm{p}>0.05$ (table 1 and 5 , figure 1)

However, there was no significant age and gender influence on the plasma values of IL-10 and TNF alpha in the results obtained from the patient with $\mathrm{p}>0.05$ (Table 2-4)

Table 1; Mean and standard deviation of IL-10 and TNF-á in patients and control subjects

\begin{tabular}{|l|l|l|l|l|l|l|}
\hline & $\begin{array}{l}\text { IL10 } \\
(\mathrm{pg} / \mathrm{ml})\end{array}$ & $\begin{array}{l}\text { TNF- } \alpha \\
(\mathrm{pg} / \mathrm{ml})\end{array}$ & HCV & HIV & HBsAg & AFB \\
\hline $\begin{array}{l}\text { mycobacterium } \\
\text { tuberculosis ( } \mathrm{n}=30)\end{array}$ & $5.6 \pm 0.1$ & $2.0 \pm 0.2$ & Negative & Negative & Negative & Positive \\
\hline $\begin{array}{l}\text { Plasmodium falciparum } \\
(\mathrm{n}=50)\end{array}$ & $5.5 \pm 0.2$ & $2.3 \pm 0.4$ & Negative & Negative & Negative & Negative \\
\hline $\begin{array}{l}\text { Plasmodium falciparum }+ \\
\text { mycobacterium } \\
\text { tuberculosis ( } \mathrm{n}=30)\end{array}$ & $8.7 \pm 0.1$ & $2.8 \pm 0.2$ & Negative & Negative & Negative & Positive \\
\hline Control (n=50) & $4.4 \pm 0.4$ & $2.1 \pm 0.3$ & Negative & Negative & Negative & Negative \\
\hline
\end{tabular}

Table 2; Comparative analysis of Mean and standard deviation of IL-10 and TNF-á in mycobacterium tuberculosis mono-infected patients based on age and gender

\begin{tabular}{|l|l|l|l|l|l|}
\hline & & $\begin{array}{l}\text { Male } \\
(\mathrm{n}=16)\end{array}$ & $\begin{array}{l}\text { Female } \\
(\mathrm{n}=14)\end{array}$ & Age: 34 -64 (n=19) & $\begin{array}{l}\text { Age: 65 and above } \\
(\text { Elderly })(\mathrm{n}=11)\end{array}$ \\
\hline \multirow{2}{*}{$\begin{array}{l}\mathrm{IL} 10 \\
(\mathrm{pg} / \mathrm{ml})\end{array}$} & Mean $\pm \mathrm{SD}$ & $5.1 \pm 0.3$ & $5.8 \pm 0.2$ & $5.7 \pm 0.3$ & $5.6 \pm 0.4$ \\
\cline { 2 - 6 } & 't' & 0 & 0.2 & \\
\cline { 2 - 6 } & $\mathrm{'} \mathrm{p}$ ' & 0.5 & & 0.429986 & \\
\hline \multirow{2}{*}{$\begin{array}{l}\mathrm{TNF}-\alpha \\
(\mathrm{pg} / \mathrm{ml})\end{array}$} & Mean $\pm \mathrm{SD}$ & $2.0 \pm 0.3$ & $2.2 \pm 0.1$ & $2.0 \pm 0.2$ & $2.3 \pm 0.2$ \\
\cline { 2 - 6 } & 't' & -0.86824 & -1.09889 & \\
\cline { 2 - 6 } & 'p' & 0.23839 & 0.19321 & \\
\hline
\end{tabular}

Table 3; Comparative analysis of Mean and standard deviation of IL-10 and TNF-á in Plasmodium mono-infected patients based on age and gender

\begin{tabular}{|l|l|l|l|l|l|}
\hline & & $\begin{array}{l}\text { Male } \\
(\mathrm{n}=23)\end{array}$ & $\begin{array}{l}\text { Female } \\
(\mathrm{n}=27)\end{array}$ & Age: 34 -64(n=28) & $\begin{array}{l}\text { Age: 65 and above } \\
(\text { Elderly })(\mathrm{n}=22)\end{array}$ \\
\hline \multirow{3}{*}{ IL10 $(\mathrm{pg} / \mathrm{ml})$} & Mean \pm SD & $5.5 \pm 0.2$ & $5.4 \pm 0.3$ & $5.5 \pm 0.3$ & $4.6 \pm 0.2$ \\
\cline { 2 - 6 } & 't' & 0.27735 & 2.49615 & \\
\cline { 2 - 6 } & 'p' & 0.403775 & $0 . .064969$ & \\
\hline \multirow{2}{*}{ TNF- $\alpha(\mathrm{pg} / \mathrm{ml})$} & Mean \pm SD & $2.1 \pm 0.2$ & $2.7 \pm 0.3$ & $2.0 \pm 0.2$ & $2.8 \pm 0.5$ \\
\cline { 2 - 6 } & 't' & -1.44437 & -1.51122 & \\
\cline { 2 - 6 } & 'p' & 0.142737 & 0.134924 & \multicolumn{2}{l|}{} \\
\hline
\end{tabular}


Table 4; Comparative analysis of Mean and standard deviation of IL-10 and TNF-á in Plasmodium falciparum + mycobacterium tuberculosis infected patients based on age and gender

\begin{tabular}{|c|c|c|c|c|c|}
\hline & & $\begin{array}{l}\text { Male } \\
(n=14)\end{array}$ & $\begin{array}{l}\text { Female } \\
(\mathrm{n}=16)\end{array}$ & Age: $34-64(n=20)$ & $\begin{array}{l}\text { Age: } 65 \text { and above } \\
\text { (Elderly) }(\mathrm{n}=10)\end{array}$ \\
\hline \multirow{3}{*}{$\begin{array}{l}\text { IL10 } \\
\text { (pg/ml) }\end{array}$} & Mean \pm SD & $8.5 \pm 0.5$ & $9.0 \pm 0.3$ & $8.9 \pm 0.4$ & $8.1 \pm 0.3$ \\
\hline & 't' & \multicolumn{2}{|l|}{-0.85749} & \multicolumn{2}{|l|}{1.6} \\
\hline & 'p' & \multicolumn{2}{|l|}{0.24076} & \multicolumn{2}{|l|}{0.12536} \\
\hline \multirow{3}{*}{$\begin{array}{l}\text { TNF- } \alpha \\
(\mathrm{pg} / \mathrm{ml})\end{array}$} & Mean \pm SD & $2.8 \pm 0.1$ & $2.7 \pm 0.3$ & $2.5 \pm 0.2$ & $3.0 \pm 0.3$ \\
\hline & ' $\mathrm{t}$ ' & \multicolumn{2}{|l|}{0.41208} & \multicolumn{2}{|l|}{-1.38675} \\
\hline & 'p' & \multicolumn{2}{|l|}{0.36012} & \multicolumn{2}{|l|}{0.14993} \\
\hline
\end{tabular}

Table 5: Comparative analysis of the results obtained from all the subjects

\begin{tabular}{|l|l|l|l|l|l|l|l|}
\hline & & $\begin{array}{l}\text { Control vs } \\
\text { mycobacterium } \\
\text { tuberculosis }\end{array}$ & $\begin{array}{l}\text { Control Vs } \\
\text { Plasmodium }\end{array}$ & $\begin{array}{l}\text { Control Vs } \\
\text { Plasmodium }+ \\
\text { mycobacterium } \\
\text { tuberculosis }\end{array}$ & $\begin{array}{l}\text { mycobacterium } \\
\text { tuberculosis Vs } \\
\text { Plasmodium }\end{array}$ & $\begin{array}{l}\text { mycobacterium } \\
\text { tuberculosis Vs } \\
\text { Plasmodium + } \\
\text { mycobacterium } \\
\text { tuberculosis }\end{array}$ & $\begin{array}{l}\text { Plasmodium Vs } \\
\text { Plasmodium }+ \\
\text { mycobacterium } \\
\text { tuberculosis }\end{array}$ \\
\hline $\begin{array}{l}\text { IL10 } \\
(\mathrm{pg} / \mathrm{ml})\end{array}$ & "t" & -1.1 & -2.46 & -10.42 & 0.10 & -3.08 & -14.31 \\
\cline { 2 - 8 } & "p" & 0.19 & 0.07 & $0.005^{* *}$ & 0.46 & $0.04 *$ & $0.002^{* *}$ \\
\hline $\begin{array}{l}\text { TNF- } \alpha \\
(\mathrm{pg} / \mathrm{ml})\end{array}$ & "t" & 0.27 & -0.4 & -1.94 & -0.67 & -2.82 & -1.11 \\
\hline & "p" & 0.40 & 0.36 & $0.04 *$ & 0.29 & $0.04 *$ & 0.19 \\
\hline
\end{tabular}

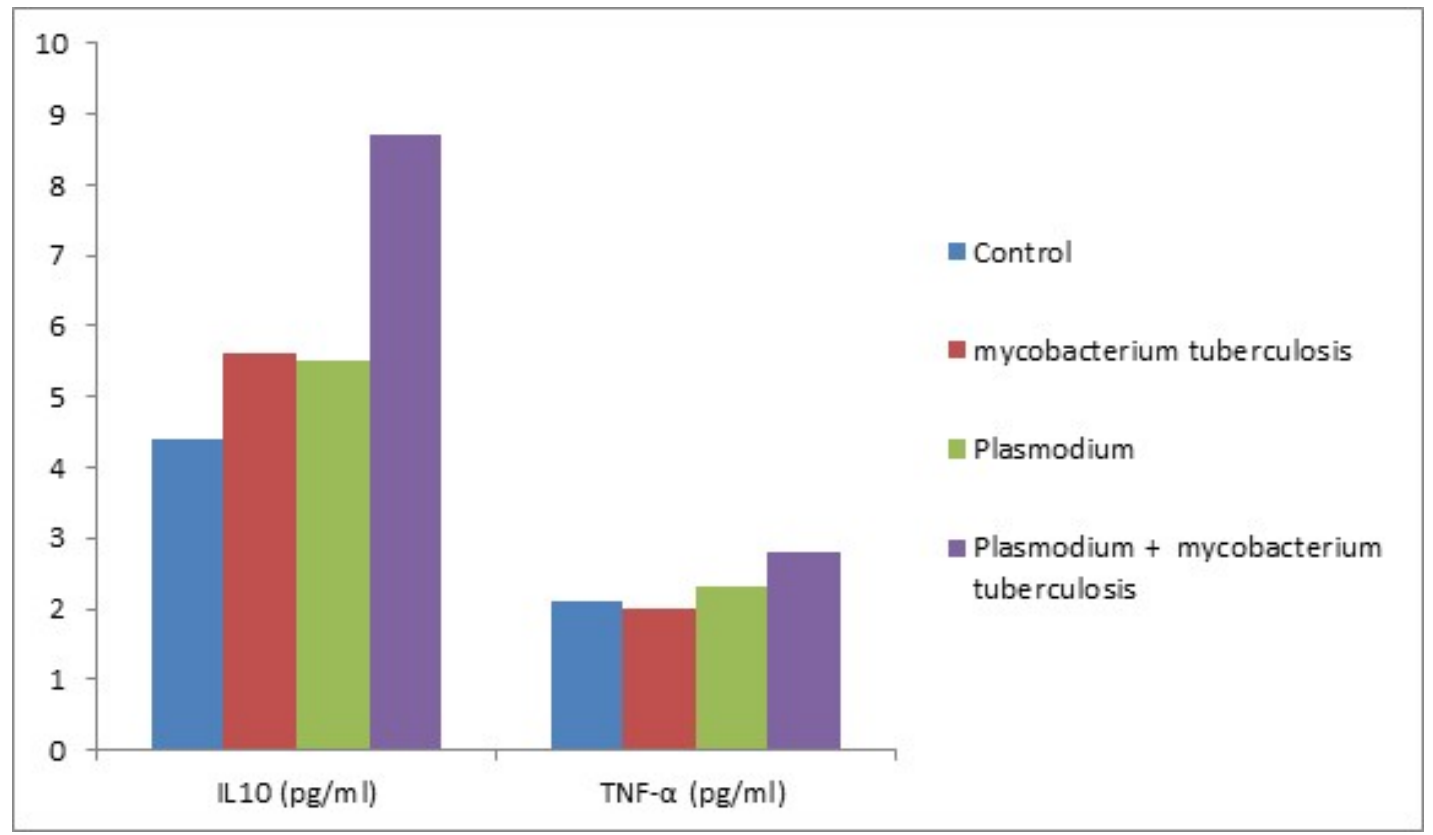

Figure 1: Comparative description of the results obtained from all the subjects 


\section{DiscussionConclusion and Recommendation Discussion}

This work was designed to determine plasma level of TNF-á and IL-10 in plasmodium co-infection with mycobacterium tuberculosis. The outcomes of this work therefore include the following: There was a significantly higher plasma IL-10 in patients co-infected with Plasmodium falciparum and mycobacterium tuberculosis than the result obtained from the control subjects, Plasmodium falciparum mono-infected patients and mycobacterium tuberculosis mono-infected subjects. There was a significantly higher plasma TNF alpha in Mycobacterium tuberculosis and Plasmodium falciparum co-infected patients than the control subjects and Mycobacterium tuberculosis monoinfected patients.

The findings of this work revealed a significant influence of co-infection of Mycobacterium tuberculosis and Plasmodium falciparum on the plasma level of IL-10 and TNF alpha compared with plasmodium and mycobacterium tuberculosis mono and non-infected subjects.

These findings could be associated with the following facts that TNF-á is a proinflammatory agent which according to Dinarello (2000) acts to make disease worse which could be due to coinfection of Mycobacterium tuberculosis and Plasmodium falciparum .

IL-10 is an anti-inflammatory cytokine which may increase in plasma as a result of increase in proinflammatory cytokine specifically in this work TNF-á in response to the severity of co-infection of mycobacterium tuberculosis and Plasmodium to enhance body defense mechanism (Walsh, 1991; Dinarello, 2000; Cavaillon, 2001; Zhang, 2007; Said et al., 2010; Feng et al., 2015). This is also due to the immunoregulatory functions of IL-10 as IL-10 is a cytokine with multiple, pleiotropic, effects in immunoregulation and inflammation. It downregulates the expression of Th1 cytokines, MHC class II antigens, and co-stimulatory molecules on macrophages. It also enhances B cell survival, proliferation, and antibody production. IL-10 can block NF-êB activity, and is involved in the regulation of the IAK-STAT signaling pathway. IL-10 predominantly inhibits lipopolysaccharide (LPS) and bacterial product mediated induction of the pro-inflammatory cytokines TNFá. IL-1â, IL-12, and IFNã. secretion from Toll-Like Receptor (TLR) triggered myeloid lineage cells (Varma et al., 2001).

TNF was thought to be produced primarily by macrophages, but it is produced also by a broad variety of cell types including lymphoid cells, mast cells, endothelial $\underline{\text { cells }}, \underline{\text { cardiac }}$ myocytes, adipose tissue, fibroblasts, and neurons. Large amounts of TNF are released in response to lipopolysaccharide, other bacterial products, and Interleukin-1 (IL-1). In the skin, mast cells appear to be the predominant source of preformed TNF, which can be released upon inflammatory stimulus (e.g., LPS).

It has a number of actions on various organ systems, generally together with IL-1 and Interleukin-6 (IL-6). It is a potent chemoattractant for neutrophils, and promotes the expression of adhesion molecules on endothelial

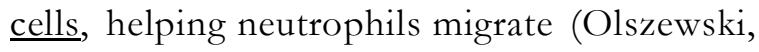
2007.

\section{Conclusion}

This work has revealed a significant increase in plasma IL-10 and TNF alpha in patients with Mycobacterium tuberculosis and Plasmodium falciparum co-infections

\section{Recommendation}

Efforts to control both diseases should be intensified, since co-infections are likely to worsen the prognosis of both diseases.

\section{References}

Braat H, Rottiers P, Hommes DW, Huyghebaert N, Remaut E, Remon JP, van Deventer SJ, 
Neirynck S, Peppelenbosch MP, Steidler L (2006). "A phase I trial with transgenic bacteria expressing interleukin-10 in Crohn's disease". Clinical Gastroenterology and Hepatology. 4 (6): 754 9. doi:10.1016/j.cgh.2006.03.028. PMID16716 $\underline{759}$

Cavaillon JM.(2001) "Pro- versus antiinflammatory cytokines: myth or reality". Cellular and Molecular Biology (Noisy-le-Grand, France). 47 (4): 695-702. PMID 11502077.

CDC - Malaria Parasites - About". CDC: Malaria. U.S. Centers for Disease Control and Prevention. Retrieved 28 December 2015.

CDC (2016)https://www.cdc.gov/globalaids/ publications/mmwr_nigeriatb.html

Cheesebrough.M. (2002). District laboratory practice in tropical countries Part 1 Monica Cheesbrough, Eds.: Cambridge University Press,.

Damien Foundation (2016) http://damienfound ation-nigeria.

Dinarello CA. Proinflammatory cytokines. 2 Chest 2000.;118(2):503-8.

Evans CA (2011). GeneXpert—a game-changer for tuberculosis control? PLoS. Med. 8:e1001064.[PMC free article] [ubMed]

Feng P, Jyotaki M, Kim A, Chai J, Simon N, Zhou M, Bachmanov AA, Huang L, Wang H (2015) "Regulation of bitter taste responses by tumor necrosis factor". Brain, Behavior, and Immunity., 49: 32-42. doi:10.1016/j.bbi.2015.04.001. PMID 25911043.

Jannike Blank, Jochen Behrends, Thomas Jacobs, and Bianca E. Schneider (2016) Mycobacterium tuberculosis Coinfection Has No
Impact on Plasmodium berghei ANKA-Induced Experimental Cerebral Malaria in C57BL/6 Mice Infect Immun. ; 84(2): 502-510.

Jannike Blank1, Lars Eggers, Jochen Behrends, Thomas Jacobs and Bianca E. Schneider1(2016).One Episode of Self-Resolving Plasmodium yoelii Infection Transiently Exacerbates Chronic Mycobacterium tuberculosis Infection Frontiers in Microbiology | Volume 7 | Article 152. 1-16

Olszewski (2007).TNF Trafficking to Human Mast Cell Granules: Mature Chain-Dependent Endocytosis. The Journal of Immunology, 2007, 178: 5701-5709,

Pawlowski A, Jansson M, Skold M, Rottenberg ME, Kallenius G (2012). Tuberculosis and HIV co-infection. PLoS. Pathog. 8:e1002464. [프 free article] [ [pubMed]

Said EA, Dupuy FP, Trautmann L, Zhang Y, Shi Y, El-Far M, Hill BJ, Noto A, Ancuta P, Peretz Y, Fonseca SG, Van Grevenynghe J, Boulassel MR, Bruneau J, Shoukry NH, Routy JP, Douek DC, Haddad EK, Sekaly RP. "Programmed death-1induced interleukin-10 production by monocytes impairs CD4+ $\mathrm{T}$ cell activation during HIV infection". Nat. Med. 2010: 16 (4): 452-9. doi:10.1038/nm.2106. PMC 4229134Freely accessible. PMID 20208540.

Spring KR, Davidson MW.(2008) 'Introduction to Fluorescence Microscopy". Nikon MicroscopyU. Retrieved 2008-09-28. https://en.wikibooks.org/ wiki/Chemical Sciences: A Manual for CSIRUGC National Eligibility Test for Lectureship and JRF/ Fluorescence microscope

Vaus David De (2002) Surveys in Social Research. Edition: 5th. . Publisher: Allen \& Unwin., St. Leonards, NSW. Publication year: 2002. 
Varma TK, Toliver-Kinsky TE, Lin CY, Koutrouvelis AP, Nichols JE, Sherwood ER ( 2001). "Cellular mechanisms that cause suppressed gamma interferon secretion in endotoxin-tolerant mice". Infection and Immunity. 69 (9): $5249-63$. doi: $10.1128 /$

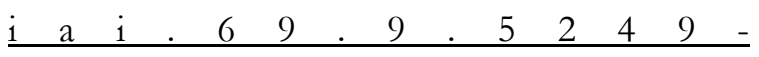
5263.2001. PMC 98633

Walsh LJ, Trinchieri G, Waldorf HA, Whitaker D, Murphy GF (1991). ’Human dermal mast cells contain and release tumor necrosis factor alpha, which induces endothelial leukocyte adhesion molecule 1". Proc. Natl. Acad. Sci. U.S.A. 88 (10):

$\begin{array}{lllll}4 & 2 & 2 & 0 & -\end{array}$

4. Bibcode:1991PNAS...88.4220W. doi:10.1073/ pnas.88.10.4220. PMC 51630. PMID 1709737.

Zhang, Jun-Ming; An, Jianxiong (2007). "Cytokines, Inflammation and Pain". International anesthesiology clinics. 45 (2): $27-37 . \quad \underline{\mathrm{d}} \mathrm{o} \mathrm{i}: 10.1007 /$ AIA.0b013e318034194e. ISSN $0020-$ 5907. PMC 2785020. PMID 17426506. 